\title{
The impact of assistance in development of different sectors of the economy - the case of Kosovo
}

\author{
Nazmi Pllana \\ Sotiraq Dhamo \\ UBT College, Pristina, Kosovo
}

\section{Keywords}

aid, donors, economic development, FTE, sales.

\begin{abstract}
Kosovo's economy is young and dynamic. It has been transformed from a decentralized economy to an open market economy. As an important place for business development, Kosovo offers several advantages such as a young and well-qualified population, natural resources, etc. Creating an environment for sustainable economic growth and improving competitiveness has been the main focus of supporting various donors (World Bank/WB, United States Agency for International Development/USAID, etc.) for Kosovo from the transition from crisis to long-term development, working closely with the Government of Kosovo to face challenges and mitigate obstacles by building a sound and market-based economy. This paper is bringing an overview of economic development in Kosovo and provides an analysis of the impact of donors in the development of various economic sectors, especially during the most delicate period that Kosovo has gone through and specifically the transition to an open market economy. The purpose of this study is to prove and demonstrate the impact of donor assistance on economic development in various sectors in Kosovo as a necessary tool to maintain the sustainability of best practices in any field of economics and based on the findings of the study to express our views.
\end{abstract}

\section{Introduction}

Kosovo has made good progress and is in an early stage of developing a more or less functional market economy. The business environment has improved, and the government has complied with the fiscal deficit rule. The informal economy remains pervasive. It particularly affects women and young people and unskilled workers. Despite strong export growth, the high trade deficit reflects a weak output base. Kosovo's medium-term development prospects are positive and on an upward trend, but it needs a stable political environment and a better business climate to attract productive investment. (World Bank, 2018)

As a partner in the implementation of reforms, Kosovo has had the continuous support of various donors such as the World Bank, USAID, European Union (EU), Deutsche Gesellschaft für Technische Zusammenarbeit/German Agency for Technical Cooperation (GTZ), Department for International Development (DFID), Danish International Development Agency (DANIDA), Swedish International Development Cooperation Agency (SIDA), etc. Here we can mention that the largest contribution was provided by USAID, World Bank, and EU.

In our work we want to bring a very important role of these donors in the development of various sectors of the economy, considering them as partners in the development of Kosovo and maintaining the stability of the economy, because cooperation is one of the main and key "elements" for achievement in a specific country.

\section{Literature review}

There is various research that maintains that aid from external donors has positively influenced the development of a country. However, the fact that many developing countries, despite high economic aid from abroad, remain at a relatively low level of development, has motivated several studies that have concluded that foreign economic aid from donors has a significant impact. negative impact on the economic development of a country.

As mentioned in the Burnside and Dollar study, "critics on both the right and the left have questioned the usefulness of foreign aid. Conservative critics hold that aid supports large, inefficient governments 
that create a bad environment for economic activity. On the other hand, the left has argued that aid agencies have imposed structural adjustment policies on reluctant countries and that these policies have not delivered the promised benefits. Several papers have attempted to measure the impact of aid on saving, investment, and growth in developing countries [Levy (1988) and Weisskopf (1972)]. Studies by Boone (1995) have concluded that aid has no significant positive impact on growth.

In general, it is found that aid has a positive impact on the economic growth of investment, expanding production and export capacity, and increasing employment. Developing countries with strong policies and high-quality public institutions have grown faster than those without. Aid has successfully supported poverty reduction and growth promotion in many countries.

Several studies of the empirical literature on aid effectiveness have attempted to assess whether aid achieves its main objectives, which is the promotion of economic development and well-being in developing countries. Lack of savings, which is crucial for investment, is generally seen as a major constraint to economic growth in these countries.

In contrast, foreign aid is significantly and negatively correlated with growth. There are various underlying causes such as dependency on aid, economic mismanagement by recipient countries, corruption, and poor coordination and cooperation between aid agencies, etc. Many researchers find that foreign aid harms growth. A high level of aid disintegrates institutional quality, increases corruption; therefore, it negatively affects growth. Gong and Zou show a negative relationship between aid and growth.

In this document, we will assess the impact of foreign aid on the Kosovo economy.

\section{Benefiting from aid and impacts on economic development}

In line with the European Council's conclusions from the Copenhagen meeting in June 1993, EU accession requires the existence of a functioning market economy and the ability to manage competitive pressure and market forces within the Union.

Monitoring of these economic criteria should also be seen in the context of the central importance of economic governance in the enlargement process. Each enlargement country prepares an economic reform program each year, which sets out a medium-term macro-fiscal policy framework and a structural reform agenda aimed at ensuring competitiveness and inclusive growth. These programs are the basis for country-specific policy guidelines, jointly adopted by the EU and, in our case, the region of Western Balkans.

Although Kosovo is in the early stages of developing a functional market economy, it has experienced economic growth, although this may be evidenced as slow growth. Recommendations of the European Union (European Commission Report, 2018, p. 38) to support long-term growth are:

increasing financial stability and improve the efficiency of public spending

addressing the basic legal and institutional factors that hinder access to finance for businesses.

increasing labor market participation and employment, especially for women and young people

Knowing that one of the main donors in Kosovo was USAID, based on the study of their programs assessment of key macroeconomic indicators was made, and concluded that some of these key indicators, such as employment, were not at the appropriate level to ensure a market-oriented economic development. We have identified while conducting the research phase for this paper in studying specific USAID projects: Kosovo Business Support (KBS), Kosovo Cluster Business Support (KCBS), and Kosovo Private Enterprise Program (KPEP) that there is a high level of unemployment $(40 \%)$ while over $98 \%$ of businesses in Kosovo employ less than 9 employees and that education system was still under the effects of the political regime of the 1990s (https://pdf.usaid.gov/pdf_docs/PA00JD9W.pdf) . According to preliminary studies of the current conditions in Kosovo before the start of this USAID project in support of economic development, targets were also set to be achieved by the program, which was sales, investments, exports, and full-time equivalent (FTE). By the end of this program (the year 2012) all these indicators marked an increase (see USAID final report for KPEP year 2013), but at the same time, three of these indicators are evidenced in our work to understand not just growth but to identify whether there was a link between the benefits received by businesses which were used directly with the increase in investment and sales revenue indicators (referred to in the report with the sales indicator) and the number of employees. For the two indicators that we have chosen in our study to measure the link between the 
assistance received and indicator results, we will briefly provide, based on the USAID annual report for 2013, the progressive levels of the indicators. To explain the background of this study we will mention that the KPEP program had four components: Component 1: Increased Competitiveness of Key Sectors (including agriculture, construction, forestry and wood products, ICT, recycling, and tourism sector), Component 2: Business Support Services (BSS), Component 3: Business Enabling Environment (BEE) and Component 4: Work Force Development (WFD). Our focus was on components one and two.

At the beginning of the project, for the sales indicator, a target was set at a $23.4 \%$ increase on an annual basis and according to the project, an increase of $52.9 \%$ was achieved compared to the annual base set as a target. Total sales growth amounted to $€ 114.7$ million (\$154.9 million), both in enterprises under component one and Business Service Providers, under component two. The progressive sales growth by sectors is presented in the chart below.

Chart 1. Progressive sales growth by sectors in the KPEP program

\title{
Sales Increase by sector (LOP)
}

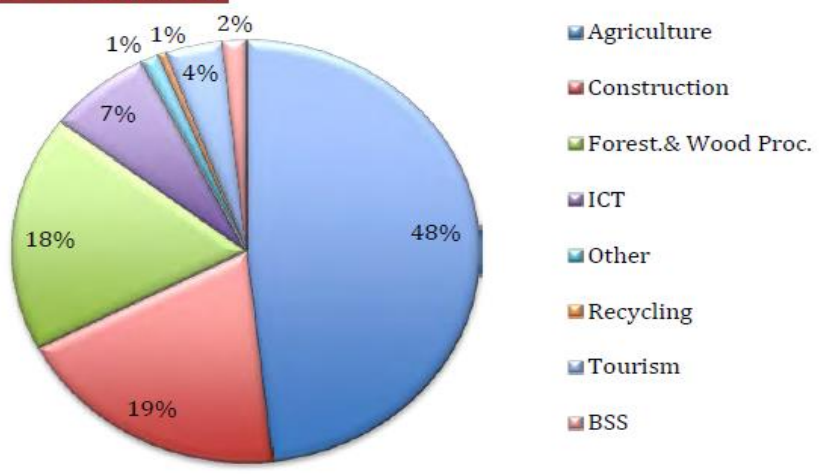

Source USAID Final Report KPEP-2013

The FTE indicator was set at 5,036 FTE jobs as a target. By the end of the project, there was an increase in FTEs by 6,727, of which 6,271 were created in Component One enterprises and 456 in Component Two, business service providers. The chart below presents the cumulative increase in FTE by sectors.

Chart 2. Progressive growth of FTE by sectors in the KPEP program

\section{FTE Increase by sector (LOP)}

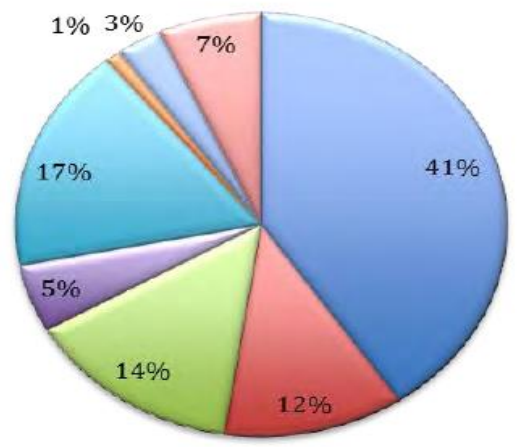

\author{
$\triangle$ Agriculture \\ a Construction \\ G Forest.\& Wood Proc. \\ $\triangle \mathrm{ICT}$ \\ $\triangle$ Other \\ $\square$ Recycling \\ Tourism \\ $\triangle$ BSS
}

Source USAID Final Report KPEP-2013

\section{Research Methodology}

We have brought this paper, which aims to show how assistance received from various donors has affected different sectors of the Kosovo economy. Primary data obtained from companies that have received assistance from various donors, for the period 2004-2012, a period that was very important in the economic reforms in Kosovo, have been used to test the impact of aid. For data collection, direct contacts with the beneficiary companies that benefited from the grants were used. For the completion of the study, two variables were taken, the sales revenues and the number of employees, in the form of Full-time 
equivalent/FTE, as the main indicators that determine the size of the enterprise, whereas the indicator of total assets was not taken into account when testing the hypothesis. The value of assets is singled out because this is a dependent variable on aid, which are nothing but sources of financing for assets, whether short-term or long-term, and the main reason for providing aid was to increase the level of investment. The number of employees indicator was converted to the FTE indicator (full-time equivalent - this indicator is determined according to the USAID donor definition. Of course, the work will have its limitations as long as it is based on these two indicators, but which are the indicators in which the data were collected from 204 enterprises for the period 2004-2012, which received donor assistance.

To realize and identify the purpose of our work and specifically to study the impact of aid at the industry level, to understand whether there will be a link between aid/support received and key indicators such as sales and FTE in each sector, we established a hypothesis.

Hypothesis: There is no link between the level of assistance and the type of sectors

The Kruskal-Wallis non-parametric test will be used to test for statistically significant changes in aid/investment by sector. Various statistical tests require the data to be quantitative and the data distribution to be normal, methods that require the fulfillment of these assumptions are also called parametric methods. But often the data that researchers have to work with is not quantitative i.e., the measurement scale may not be intermittent or in the form of a report, or the data distribution may not be normal. In such cases, statisticians suggest the use of methods called nonparametric methods unlike methods free from distributions. Also, statisticians suggest that if the assumptions required for the various statistical tests if the assumptions are met it would be better to use parametric methods as more robust testing methods. Several parametric and non-parametric tests are known in practice. In general, for one to be considered a nonparametric method it must meet at least one of the following conditions (W. J. Conover 1980):

-the method can be used for data measured at the nominal scale

-the method can be used for data measured at the usual scale

- the method can be used for data measured at the interval scale or in the form of a report when the assumption for probabilistic distribution is not met.

There are many non-parametric methods used for various statistical tests, among which we can mention the criterion of signs, Wilcoxon signed-rank test, Mann-Whitney U test, Kruskal-Wallis test, Friedman test, ranking correlation coefficient, etc.

If tested to compare more than two populations and if assumptions about normal distribution, constant variances, and independent observations would be met, the most appropriate parametric analysis, in this case, would be analysis of variance, but in case of non-fulfillment of the assumption for normal distribution the nonparametric test suggested by statisticians is the Kruskal-Wallis test. This test requires that data be collected for selections taken from different populations, that the data be sorted from smallest to largest, and that the distribution pattern of these rankings is viewed according to the different choices included in the analysis.

The statistical hypotheses that are tested in the case of this test are:

$H_{0}: k$ populations are identical

Ha: $k$ populations are not identical

When the basic hypothesis is true, the distribution approximates the distribution $\chi^{2}$ with a k-1 degree of freedom, where $\mathrm{k}$ is the number of degrees of freedom. The observed $\chi^{2}$ value is calculated:

$$
H=\frac{12}{n(n+1)} \geq \frac{T_{i}^{2}}{n_{i}}-3(n+1)
$$

Where:

n-total number of observations

$\mathrm{n}_{\mathrm{i}}$-number of observations for each election

$\mathrm{T}_{\mathrm{i}}$-total ranks for each election

If the basic hypothesis is rejected it will be further analyzed by performing multiple comparisons to test between which populations these differences exist based on the Dunn-Bonferroni procedure. 


\section{Results}

To confirm the hypothesis "There is no link between the level of assistance and the type of sectors" it was tested whether there are statistically significant differences in terms of assistance in different sectors.

Initially, a general description will be given based on the impact of the assistance on the growth of the two enterprise size indicators as follows. The enterprises that have benefited from the aid, their income have increased significantly from 2004 to 2012. Specifically, from 78,328,070 euros to 212,402,000 euros, or by about $171.17 \%$, a very significant increase. This trend of this indicator is only increasing without experiencing any decrease, unlike the value of aid which for the years 2010 and 2005 had the lowest values in the level of income, respectively for 2005 we have an increase of income by $35.16 \%$ compared with the first year 2004 for which the assistance was received and in 2010 we have an increase of 108.86\% of income compared to the first year 2004 (see chart no. 3).

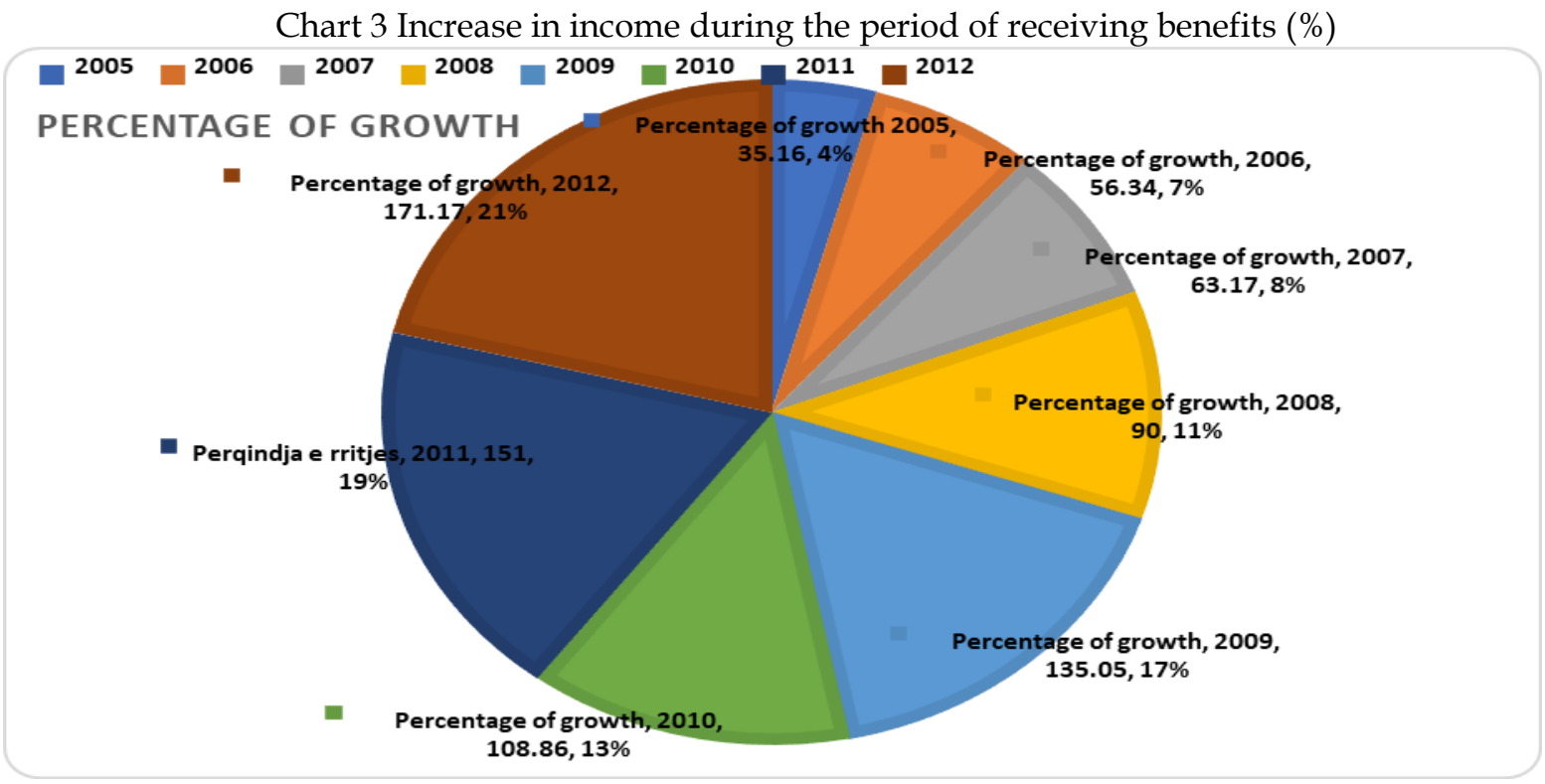

Source: data collected from USAID projects Kosovo Business Support (KBS), Kosovo Cluster Business Support

(KCBS), and Kosovo Private Enterprise Program (KPEP)-processed from the author

The second indicator taken in our study is FTE and has the same trend as sales revenue; for the period from 2004 to 2012 has increased during the period of receiving benefits, which shows that the number of employees in enterprises has increased (see Chart 4).

Chart 4. FTE for businesses that have received donor assistance

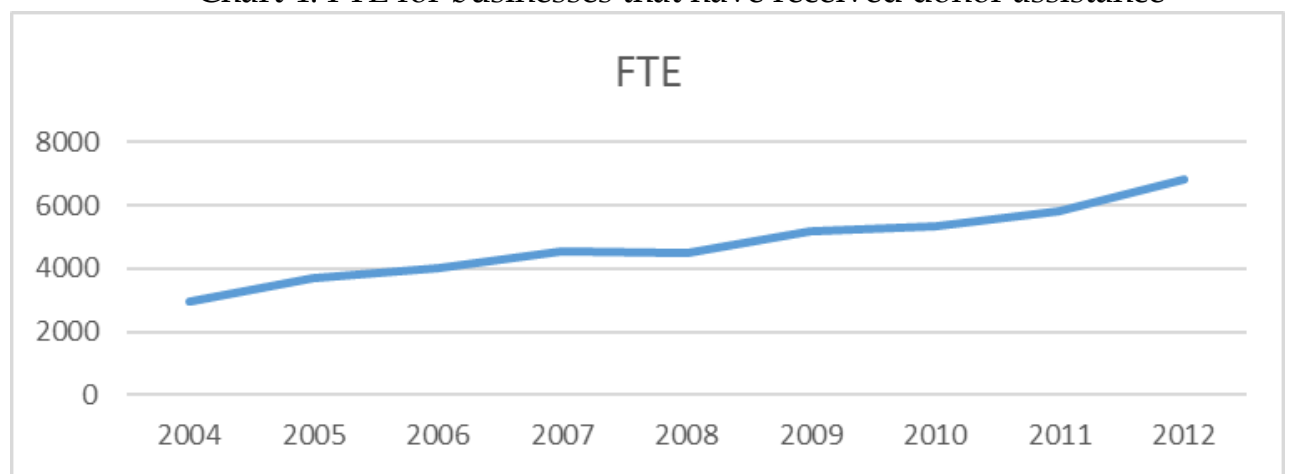

Source: data collected from USAID projects Kosovo Business Support (KBS), Kosovo Cluster Business Support

(KCBS), and Kosovo Private Enterprise Program (KPEP)-processed from the author

The distribution of aid by sectors is presented in Chart 5 . The sectors that have received the most assistance during the period 2004-2012 from donors have been construction (39.79\%) and agriculture with 
$32.58 \%$. While other sectors have had the lowest share of benefits received such as livestock with $11.17 \%$ and sectors that have even lower weight is Recycling $(0.16 \%)$, tourism $(1.61 \%)$, others $(0.28 \%)$.

\section{Chart 5. Distribution of aid by sectors}

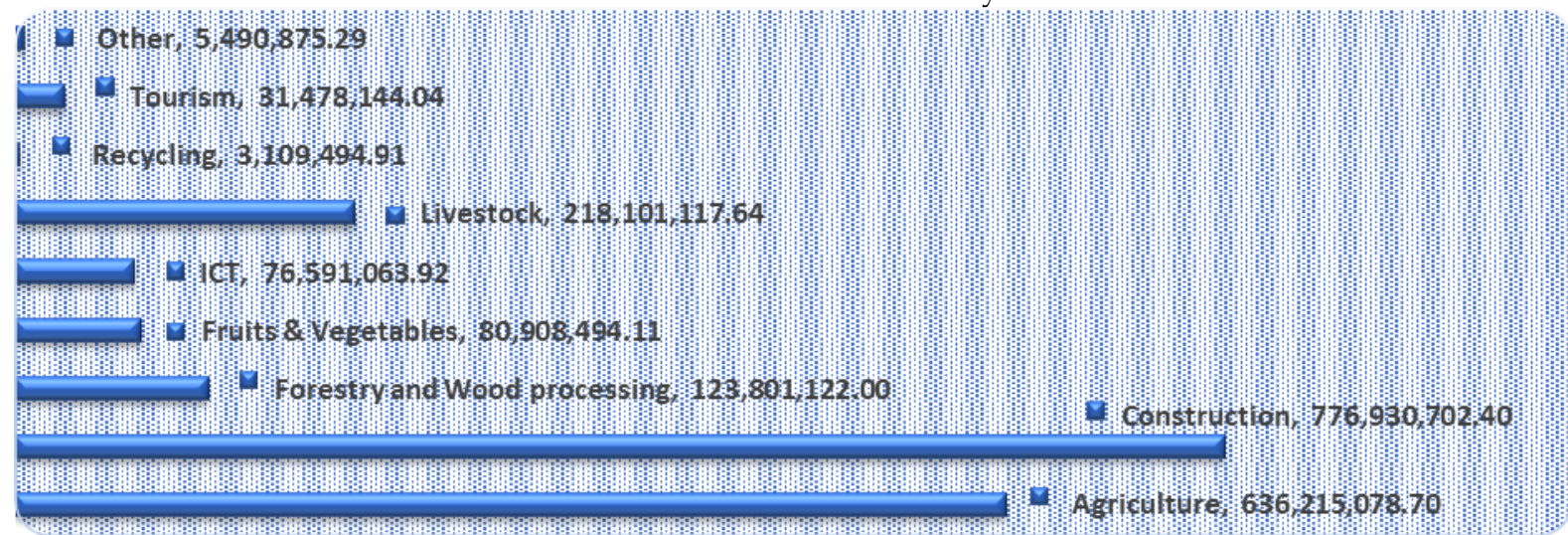

Source: data collected from USAID projects Kosovo Business Support (KBS), Kosovo Cluster Business Support (KCBS), and Kosovo Private Enterprise Program (KPEP)-processed from the author

Chart 6. Distribution of aid by sectors in percentage

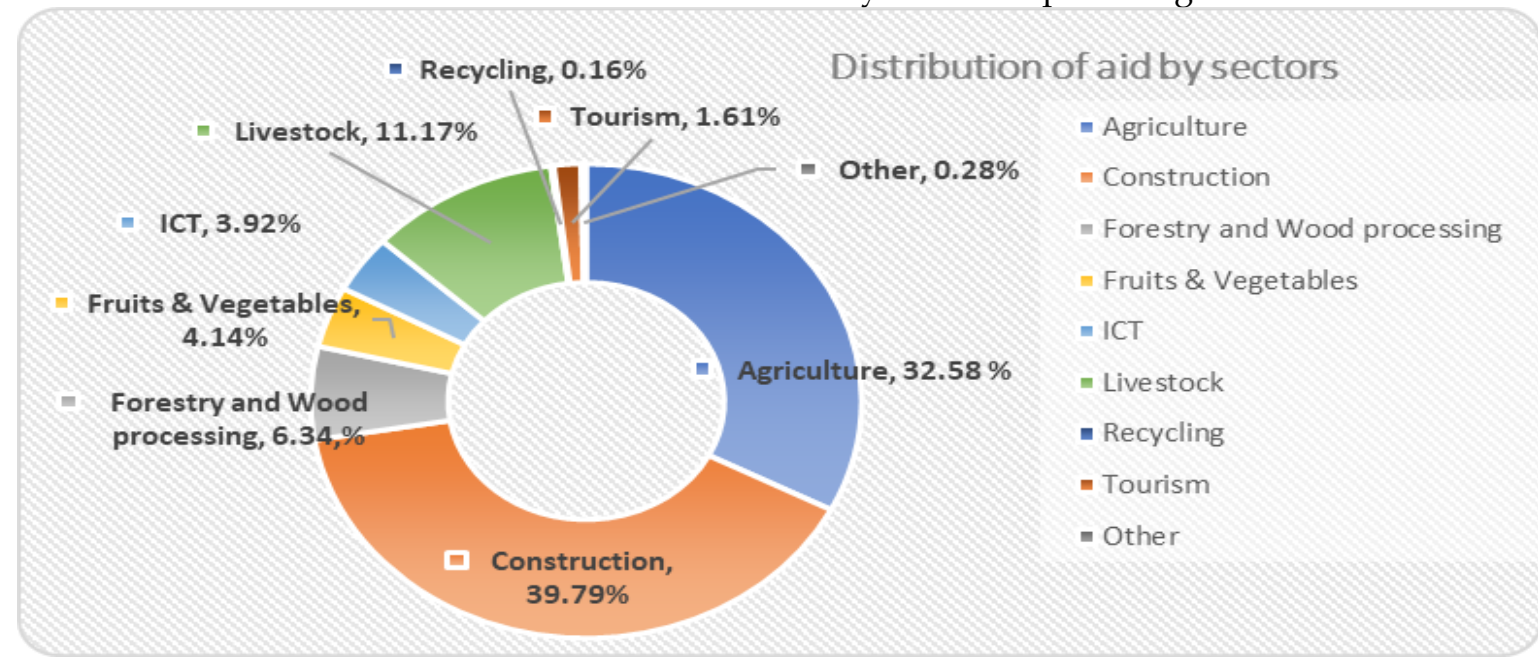

Source: data collected from USAID projects Kosovo Business Support (KBS), Kosovo Cluster Business Support (KCBS), and Kosovo Private Enterprise Program (KPEP)-processed from the author

Given that nine sectors were supported and are part of our study (Construction, Agriculture, Fruits and vegetables, Livestock, Recycling, Forestry and wood processing, ICT, Tourism, and some minor sectors marked as "Others"), we considered that the most appropriate statistical test to be applied in this case is the Kruskal- Wallis test. We have tested whether the aid received in all these sectors is the same. The purpose of this hypothesis raised by us is the fact, to look at each sector and assess the impact of donor assistance and whether each indicator would depend on different sectors from the aid. The main reason for raising this hypothesis was the literature reviewed where the independent variable- sector was tested in some cases and studies concluded that sectors are an influential factor in donor's aid direction. That is, donors during their decisions also start from the industry in which they want to make their investments. Consequently, we raise the statistical hypotheses as follows:

$H_{0}:$ Aid in all sectors is the same

$\mathrm{H}_{1}$ : Aid in all sectors is not the same 1).

Given that the value $\mathrm{p}<0.001$, indicates that aid in the nine sectors is not statistically the same (Table 
Table 1: Statistical test results

\begin{tabular}{|c|c|c|c|}
\hline \multicolumn{4}{|l|}{ Hypothesis test summary } \\
\hline Hypothesis zero & Test & ig. & Decision \\
\hline $\begin{array}{l}\text { The distribution of aid } \\
\text { is the same through the } \\
\text { categories of sectors. }\end{array}$ & $\begin{array}{l}\text { Independence } \\
\text { Test Kruskal-Wallis }\end{array}$ & 000 & $\begin{array}{l}\text { Hypothesis } \\
0 \text { is rejected }\end{array}$ \\
\hline
\end{tabular}

Source: data collected from USAID projects Kosovo Business Support (KBS), Kosovo Cluster Business Support (KCBS), and Kosovo Private Enterprise Program (KPEP)-processed from the author

Regarding the above, we can say that hypothesis $\mathrm{H} 0$ is rejected so the aid is not the same in all sectors.

While the statistical testing showed that there are significant changes, we decided to further deepen the testing in the component sectors for which assistance has been provided, and multiple comparisons were performed, the schematic presentation of all possible comparisons is presented below:

Chart 7 The effect of aid distribution across sectors

Pairwise Comparisons of Sektori

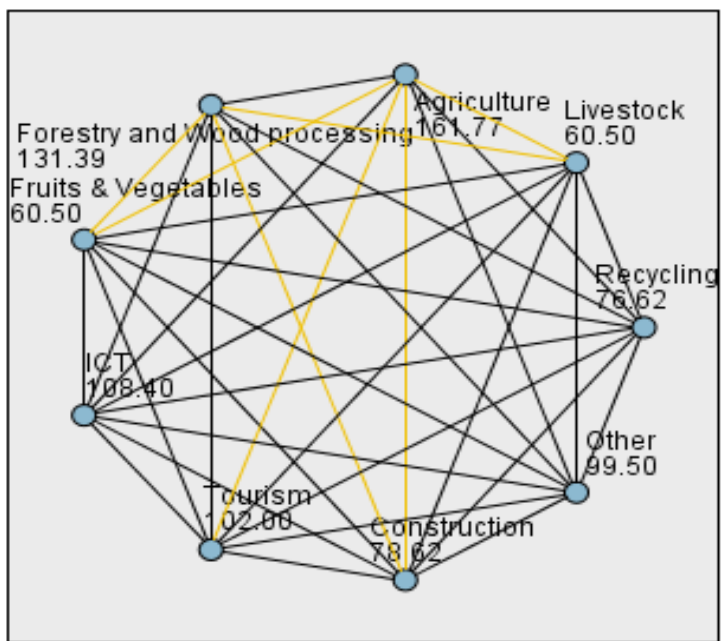

Source: data collected from USAID projects Kosovo Business Support (KBS), Kosovo Cluster Business Support (KCBS), and Kosovo Private Enterprise Program (KPEP)-processed from the author

Multiple comparisons were performed for each combination of the two sectors, based on the Dunn procedure. Statistical tests showed that there are statistically significant differences in aid/investment between these sectors:

(Construction Sector-Agriculture sector $\mathrm{p}<0.05$ )

(Livestock sector - Forestry and wood processing sector $\mathrm{p}<0.05$ )

(Forests and wood processing sector - Fruits and Vegetables sector $\mathrm{p}<0.05$ )

(Forestry and wood processing sector - Construction sector $\mathrm{p}<0.05$ )

(Tourism sector - Agriculture sector $\mathrm{p}<0.05$ )

(Fruit and Vegetable sector- Agriculture sector $\mathrm{p}<0.05$ )

(Livestock sector- Agriculture sector $\mathrm{p}<0.05$ )

All other cross-sectoral combinations indicated that there were no significant aid/investment differences between them.

As can be seen, the impact of aid is more distinct in the construction, agriculture, and tourism sectors. 
At the end of the data analysis, we can say that in Kosovo the assistance received from donors has had its effects. The values of the aid received by the enterprises have influenced the increase of their size, which evidences the fact that the more an enterprise would receive aid, the more its size would increase (in terms of income and FTE). But the test showed that there is no link between the level of assistance and the type of sector that would benefit. Our argument for raising this hypothesis was the fact that in the initial developments of a country like Kosovo that emerged after the war, aid "would not have" the priorities of certain sectors to develop it. But the testing of this hypothesis as we said was rejected and it was found that there is a connection between them and especially in certain sectors such as construction, tourism and agriculture have had the greatest impact compared to other sectors where their effect was statistically unimportant.

\section{Limitations and direction for future research}

This paper comes as a study of a very special but also very important field seen in the view of the benefits of donor assistance in various sectors of the economy. The limitation of the paper exists especially in the in-depth study of this development as the data analyzed in our paper although belong to a long period from 2004-2012 again, they belonged to only the two main indicators of the specific size of entities and categories and in specific sectors.

An additional limitation is that the data were obtained only from the work and assistance of a USAID donor, who, although the largest and most important donor, was not the only one in Kosovo. The author of this study was not able to obtain data that could be comparable or complementary to the information received from the USAID donor. Therefore, it remains to be explored in future research as an additional opportunity to enrich this topic.

Due to the difficulty of data collection, since the project funded by foreign donors ended in 2012 the analysis of the study did not include the period after 2012. Exactly this period will have to be analyzed to see if it has continued and whether confirms the finding in our paper that donor assistance has affected economic development in general and in its specific sectors.

To the readers of this study, we tried to give an overview and an impetus to conduct further studies on donor assistance that benefit not only governments but also enterprises themselves, thus leading to increased quality of financial information, absolutely crucial for decision-making purposes.

\section{Conclusions}

Donors have contributed to improving the situation of Kosovo as an investment destination, ensuring adoption and compliance as much as possible, throughout the private sector of Kosovo, with the relevant EC directives, taking into account local business conditions and the stage of economic development. Our study indicated that receiving assistance from different companies operating in different sectors did not depend on each other, but for specific sectors, it has a statistically significant impact such as the construction, agriculture, and tourism sectors.

What is further required is to strengthen even more the coordination of the main supporting actors in Kosovo, such as USAID, World Bank, and EU, to continue the support of donors and to continuously seek to expand their support due to satisfactory results expressed in general macro and microeconomic indicators in Kosovo. One recommendation from this paper is that donor support should be spread throughout economic sectors of Kosovo, perhaps not evenly, but in all sectors, and not to focus only on construction, agriculture, and tourism. 
Appendices:

\begin{tabular}{|c|c|c|c|c|c|}
\hline Sample1-Sample2 & $\begin{array}{l}\text { Test } \\
\text { Statistic }\end{array}$ & $\begin{array}{l}\text { Std. } \\
\text { Error }\end{array}$ & $\begin{array}{l}\text { Std. Test } \\
\text { Statistic }\end{array}$ & Sig. & Adj.Sig. \\
\hline Construction-Agriculture & -83.146 & 11.079 & -7.505 & .000 & .000 \\
\hline $\begin{array}{l}\text { Livestock-Forestry and Wood } \\
\text { processing }\end{array}$ & -70.886 & 14.591 & -4.858 & .000 & .000 \\
\hline $\begin{array}{l}\text { Fruits \& Vegetables-Forestry and } \\
\text { Wood processing }\end{array}$ & -70.886 & 15.132 & -4.685 & .000 & .000 \\
\hline $\begin{array}{l}\text { Construction-Forestry and Wood } \\
\text { processing }\end{array}$ & -52.767 & 13.866 & -3.806 & .000 & .005 \\
\hline Livestock-Tourism & -41.500 & 16.131 & -2.573 & .010 & .363 \\
\hline Livestock-ICT & -47.900 & 19.087 & -2.510 & .012 & .435 \\
\hline Fruits \& Vegetables-Tourism & -41.500 & 16.622 & -2.497 & .013 & .451 \\
\hline Fruits \& Vegetables-ICT & -47.900 & 19.503 & -2.456 & .014 & .506 \\
\hline $\begin{array}{l}\text { Recycling-Forestry and Wood } \\
\text { processing }\end{array}$ & -54.761 & 28.637 & -1.912 & .056 & 1.000 \\
\hline Construction-ICT & -29.781 & 18.538 & -1.606 & 108 & 1.000 \\
\hline Construction-Tourism & -23.381 & 15.478 & -1.511 & .131 & 1.000 \\
\hline Recycling-ICT & -31.775 & 31.169 & -1.019 & .308 & 1.000 \\
\hline Livestock-Other & -39.000 & 38.400 & -1.016 & .310 & 1.000 \\
\hline Fruits \& Vegetables-Other & -39.000 & 38.609 & -1.010 & .312 & 1.000 \\
\hline Recycling-Tourism & -25.375 & 29.452 & -.862 & .389 & 1.000 \\
\hline Livestock-Recycling & -16.125 & 27.940 & -.577 & .564 & 1.000 \\
\hline Fruits \& Vegetables-Recycling & -16.125 & 28.226 & -.571 & .568 & 1.000 \\
\hline Construction-Other & -20.881 & 38.130 & -.548 & .584 & 1.000 \\
\hline Recycling-Other & -22.875 & 45.626 & -.501 & .616 & 1.000 \\
\hline Fruits \& Vegetables-Livestock & .000 & 13.767 & .000 & 1.000 & 1.000 \\
\hline Other-Tourism & 2.500 & 39.513 & .063 & .950 & 1.000 \\
\hline Recycling-Construction & 1.994 & 27.568 & .072 & .942 & 1.000 \\
\hline Other-ICT & 8.900 & 40.809 & .218 & .827 & 1.000 \\
\hline Tourism-ICT & 6.400 & 21.238 & .301 & .763 & 1.000 \\
\hline $\begin{array}{l}\text { Other-Forestry and Wood } \\
\text { processing }\end{array}$ & 31.886 & 38.910 & .819 & .413 & 1.000 \\
\hline $\begin{array}{l}\text { ICT-Forestry and Wood } \\
\text { processing }\end{array}$ & 22.986 & 20.093 & 1.144 & .253 & 1.000 \\
\hline Fruits \& Vegetables-Construction & 18.119 & 12.996 & 1.394 & .163 & 1.000 \\
\hline Livestock-Construction & 18.119 & 12.362 & 1.466 & .143 & 1.000 \\
\hline Other-Agriculture & 62.265 & 38.006 & 1.638 & .101 & 1.000 \\
\hline $\begin{array}{l}\text { Tourism-Forestry and Wood } \\
\text { processing }\end{array}$ & 29.386 & 17.310 & 1.698 & .090 & 1.000 \\
\hline $\begin{array}{l}\text { Forestry and Wood processing- } \\
\text { Agriculture }\end{array}$ & 30.379 & 13.521 & 2.247 & .025 & .887 \\
\hline ICT-Agriculture & 53.365 & 18.281 & 2.919 & .004 & .126 \\
\hline Recycling-Agriculture & 85.140 & 27.396 & 3.108 & .002 & .068 \\
\hline Tourism-Agriculture & 59.765 & 15.170 & 3.940 & .000 & .003 \\
\hline Fruits \& Vegetables-Agriculture & 101.265 & 12.627 & 8.020 & .000 & .000 \\
\hline Livestock-Agriculture & 101.265 & 11.974 & 8.457 & .000 & .000 \\
\hline
\end{tabular}

Each row tests the null hypothesis that the Sample 1 and Sample 2 distributions are the

Asymptotic significances (2-sided tests) are displayed. The significance level is .05.

Correlations $^{\mathrm{a}}$ 


\begin{tabular}{|c|c|c|c|c|c|}
\hline & & & log Sales & Log FTE & Log Investment \\
\hline Spearman's rho & $\begin{array}{l}\text { Log FTE } \\
\text { Log Investment }\end{array}$ & $\begin{array}{l}\text { Correlation Coefficient } \\
\text { Sig. (2-tailed) } \\
\mathrm{N} \\
\text { Correlation Coefficient } \\
\text { Sig. (2-tailed) } \\
\mathrm{N} \\
\text { Correlation Coefficient } \\
\text { Sig. (2-tailed) } \\
\mathrm{N}\end{array}$ & $\begin{array}{c}1.000 \\
. \\
42 \\
.450^{\star *} \\
.003 \\
42 \\
.821^{*} \\
.023 \\
7\end{array}$ & $\begin{array}{c}.450^{* *} \\
.003 \\
42 \\
1.000 \\
. \\
42 \\
.250 \\
.589 \\
7\end{array}$ & $\begin{array}{c}.821^{*} \\
.023 \\
7 \\
.250 \\
.589 \\
7 \\
1.000 \\
. \\
7\end{array}$ \\
\hline
\end{tabular}

**. Correlation is significant at the 0.01 level (2-tailed).

*. Correlation is significant at the 0.05 level (2-tailed).

a. Sector $\_1=1.00$

Sector_1 = Agriculture

Correlations $^{\mathrm{a}}$

\begin{tabular}{|c|c|c|c|c|c|}
\hline & & & Log Sales & Log FTE & Log Investment \\
\hline \multirow{9}{*}{ Spearman's rho } & \multirow{3}{*}{ Log Sales } & Correlation Coefficient & 1.000 & $.434^{* *}$ & $.552^{\text {** }}$ \\
\hline & & Sig. (2-tailed) & . & .000 & .000 \\
\hline & & $\mathrm{N}$ & 108 & 106 & 44 \\
\hline & \multirow{3}{*}{ Log FTE } & Correlation Coefficient & $.434^{* *}$ & 1.000 & .250 \\
\hline & & Sig. (2-tailed) & .000 & . & .106 \\
\hline & & $\mathrm{N}$ & 106 & 106 & 43 \\
\hline & \multirow{3}{*}{ log Investment } & Correlation Coefficient & $.552^{* *}$ & .250 & 1.000 \\
\hline & & Sig. (2-tailed) & .000 & .106 & . \\
\hline & & $\mathrm{N}$ & 44 & 43 & 44 \\
\hline
\end{tabular}

**. Correlation is significant at the 0.01 level (2-tailed).

a. Sector_ $1=2.00$

Sector_1 $=$ Other sectors

Correlations ${ }^{\mathrm{a}}$

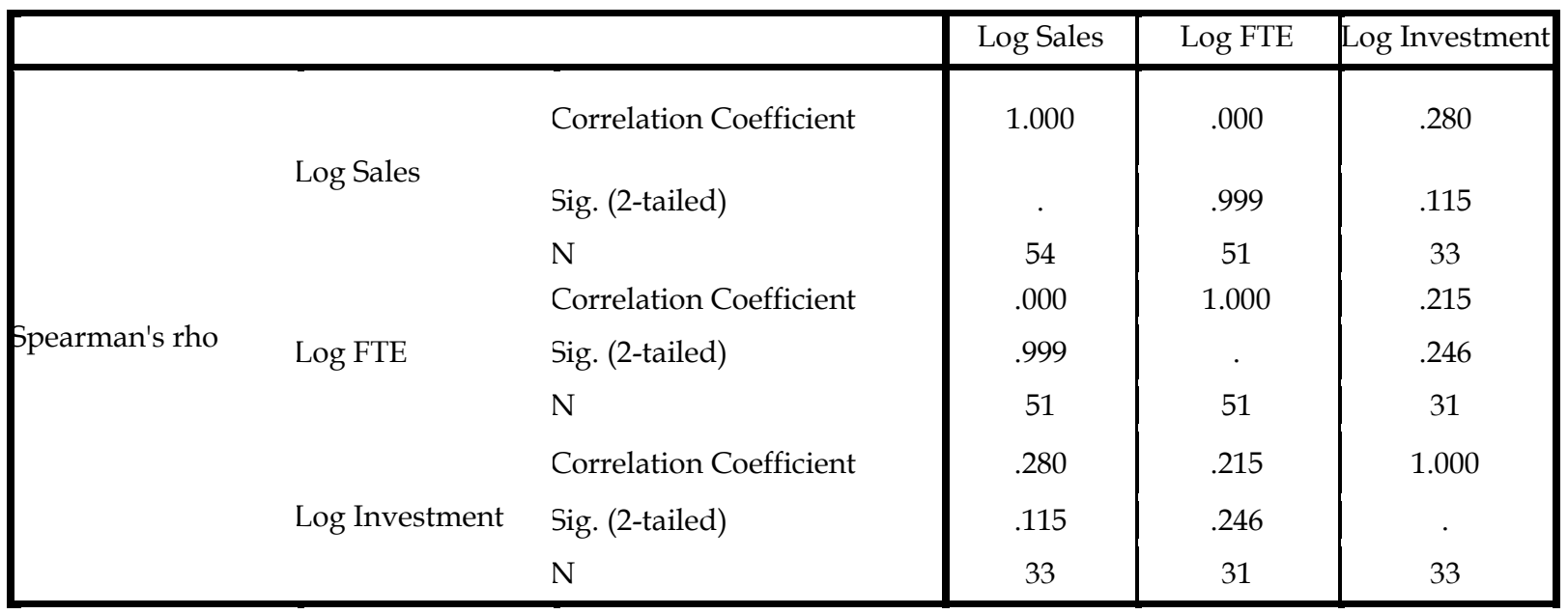

Sector_ $1=3.00$

Conference proceedings of the Centre for Business \& Economic Research, ICBED-2021, 10-12 June 
Pairwise Comparisons of Sektori_1

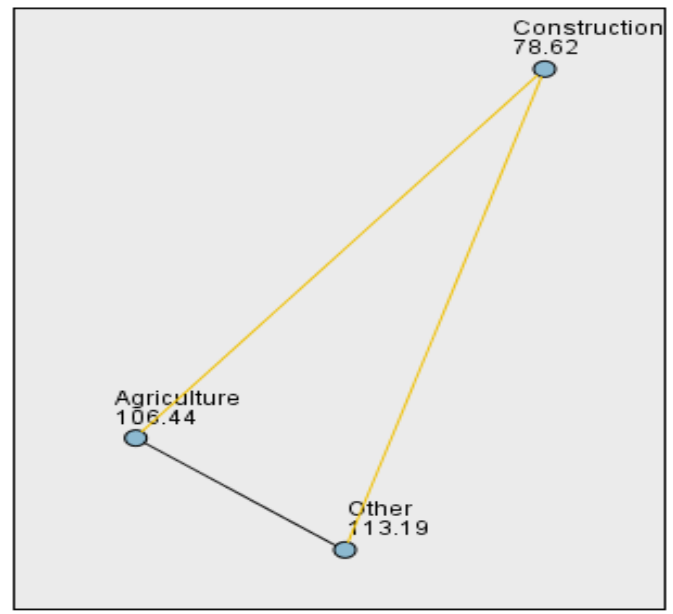

Each node shows the sample average rank of Sektori_1.

\begin{tabular}{|lrrrrr|}
\hline Sample1-Sample2 & $\begin{array}{c}\text { Test } \\
\text { Statistic }\end{array}$ & $\begin{array}{c}\text { Std. } \\
\text { Error }\end{array}$ & $\begin{array}{c}\text { Std. Test } \\
\text { Statistic }\end{array}$ & Sig. & Adj.Sig. \\
\cline { 2 - 7 } Construction-Agriculture & -27.825 & 9.581 & -2.904 & .004 & .011 \\
\hline Construction-Other & -34.566 & 10.839 & -3.189 & .001 & .004 \\
\hline Agriculture-Other & -6.741 & 8.781 & -.768 & .443 & 1.000 \\
\hline
\end{tabular}

Each row tests the null hypothesis that the Sample 1 and Sample 2 distributions

Asymptotic significances (2-sided tests) are displayed. The significance level is .05.

\section{References}

Beest Van F. Braam G. Boelens S. (2009) Quality of Financial Reporting: measuring qualitative characteristics; https://www.ru.nl/economie/onderzoek/nice-working-papers.

Botosan, C. (2004). Discussion of a framework for the analysis of risk communication. The International Journal of Accounting, 39, 289-295.

Commission of the European Communities. 2008. "Report from the Commission to the Council and the European Parliament on the Operation of Regulation (EC) No 1606/2002 of 19 July 2002 on the Application of International Accounting Standards." Commission of the European Communities, Brussels.

Final Report (January 12th, 2009) The European Union's National Action program for KOSOVO; This project is funded by the European Union and implemented by the European Commission.

Henri Fortin, Ana Cristina Hirata Barros, Kit Cutler (2010) Improving Corporate Financial Reporting to Support Regional Economic Development; The International Bank for Reconstruction and Development/The World Bank/ edition.

http://pubdocs.worldbank.org/en/423771524155944422/Kosovo-Snapshot-Spring2018.pdf.

Parsons, L.M. 2003. Is accounting information from nonprofit organizations useful to donors? A review of charitable giving and value-relevance. Journal of Accounting Literature. 22: 104-129.

Trussel M. John; Parsons M. Linda Financial Reporting Factors Affecting Donations to Charitable Not-for-Profit Organizations.

Trussel, J. M. and J. S. Greenlee. 2004. A financial rating system for charitable nonprofit organizations. Research in Government and Nonprofit Accounting 11 (forthcoming).

Weisbrod, B. A. and N. D. Dominguez. 1986. Demand for collective goods in private non-profit markets: Can fundraising expenditures help overcome free rider behavior? Journal of Public Economics 30: 83-96.

https://pdf.usaid.gov/pdf_docs/PA00JD9W.pdf.

Burnside, Craig and Dollar, David. 1997. Aid, Policies, and Growth: The World Bank

Policy Research Department; Macroeconomic and Growth Division, June 1997.

Levy, Victor. Aid and Growth in Sub-Saharan Africa: The recent experience; European Economic Review, 1988, vol. 32, issue 9, 1777-1795.

Weisskopf, Thomas E. The impact of foreign capital inflow on domestic savings in underdeveloped countries; Journal of International Economics, 1972, vol. 2, issue 1, 25-38. 
Boone, Peter. 1995. Politics and the effectiveness of foreign aid; Centre for Economic Performance; London School of Economics and Political Science; ISBN 0753003252.

Gong, Liutang and Zou, Heng-fu, Foreign Aid Reduces Labor Supply and Capital Accumulation (February 2001). Review of Development Economics, Vol. 5, Issue 1, pp. 105-118, 2001. 